\title{
A Tribute to Victor Kent Prest 1913-2003
}

\author{
A. S. Dyke ${ }^{1}$, D. A. Hodgson ${ }^{1}$, E. L. Bousfield ${ }^{2}$, and R. E. BedFORD ${ }^{3}$ \\ ${ }^{1}$ Terrain Sciences Division, Geological Survey of Canada, 601 Booth Street, Ottawa, Ontario K1A 0E8 Canada \\ 2 301-540 Dallas Road, Victoria, British Columbia V8V 4X9 Canada \\ ${ }^{3} 524$ Penhill Avenue, Ottawa, Ontario K1G 0V6 Canada
}

Dyke, A. S., D. A. Hodgson, E. L. Bousfield, and R. E. Bedford. 2004. A Tribute to Victor Kent Prest 1913-2003. Canadian Field-Naturalist 118(4): 626-629.

With the death of Dr. Victor Kent Prest on 2003 September 26, Canada lost one of its most distinguished, best-known, and most influential Quaternary geologists. Vic was active as a leader of Canadian Quaternary science for a remarkably long time and he positively influenced the careers of almost everyone else in the field in this country as well as his many friends abroad. His work became basic to discoveries by other scientists in related fields such as plant and animal biogeography, both terrestrial and aquatic ${ }^{4,5,6}$. He came to personify the Quaternary Geology of Canada both domestically and internationally. This identity arose from his unstinting and deep interest in the subject, his long view of the evolution of ideas, his intimate knowledge of the ever-growing knowledge base, and especially the very genuine interest he took in the work of all others. Tentative, junior researchers and graduate students always met with as much respect and encouragement as did his senior colleagues and Vic often took the time to send notes of encouragement and compliment.

Victor K. Prest was born in Edmonton Alberta, 2 April 1913, the only child of John (Jack) Prest and Elizabeth Buckley (Prest). His early education was obtained at the MacKay Avenue School in Edmonton. In 1925 the family moved to Toronto for a brief period, and relocated in London, Ontario, where Vic completed his early schooling at Tecumseh Public School and London South Collegiate High School. In 1930 the Prests moved to Winnipeg where Victor completed his secondary education at Kelvin High School. Unrealized by Vic, his future wife Patricia Horder was also attending Kelvin, in the same grade, but in a different classroom. Her father, a Canadian Pacific Railway official, had been transferred from Montreal to Winnipeg in 1926. Vic received his B. Sc. (Honours) from the University of Manitoba in 1935 and his M. Sc. a year later. Growing stronger during these university days was his friendship with Patricia Horder who was active in music, drama, and art, and in the Canadian Girl Guide Association.

Vic worked as a summer assistant for the Manitoba Mines Branch in 1934 and the Geological survey of Canada in 1935 and 1936. While registered for Ph.D. studies at the University of Toronto, Vic was
Party Chief, Ontario Department of Mines, from 19371940, mainly mapping bedrock outcrops in Northern Ontario. In 1941 Vic received his Ph.D. degree at "Toronto" where he also served as an assistant in both the Geology Department and the Royal Ontario Museum and later as Lecturer. The newly minted Dr. Prest joined the International Nickel Company as a geologist for a year (1941-1942).

Vic and Pat were married in Toronto in 1942 and moved immediately to Harbour Grace, Newfoundland, where Vic served with the RCNVR from 1942-1945. Their first child, Sherron (Sherry) Gail was born there in 1944. Following the surrender of Nazi Germany in early May, 1945, Lieutenant Prest was a member of the naval party accepting the surrender of submarine U190 in St. John's Harbour.

During the next five years Vic was a permanent staff member of the Ontario Department of Mines, based in Toronto, where his son Wayne Horder Prest was born in 1946. In 1950, he transferred to the Geological Survey of Canada in Ottawa. Vic served as Chief of the Pleistocene Engineering and Groundwater Section, first in a third-floor office of the Victoria Memorial Museum building and, following its completion in 1960 , in the newly constructed Geological Survey building on Booth Street. Vic formally retired from government service in 1979, but maintained a consultantship office at the Booth St. building until very recently.

Dr. Victor K. Prest is probably best known because of the Glacial Map of Canada (Prest et al. 1968), a work of such veracity that it has yet to be superceded for the country as a whole. This map followed an earlier version initiated by J. Tuzo Wilson, to which Vic contributed as co-compiler (Wilson et al. 1959). The 1968 Glacial Map was followed by the beautiful blueshaded "pancake map" depicting the Retreat of Wisconsin and Recent Ice in North America (Prest 1969), and his masterful Quaternary Geology chapter in the Geology of Canada volume (Prest 1970). That trilogy was the masterpiece of a generation, which adorned many an academic hallway and classroom. Its impact places it among the most outstanding contributions of the Geological Survey of Canada (GSC) and fixes it as its premier Quaternary contribution. It was the most 


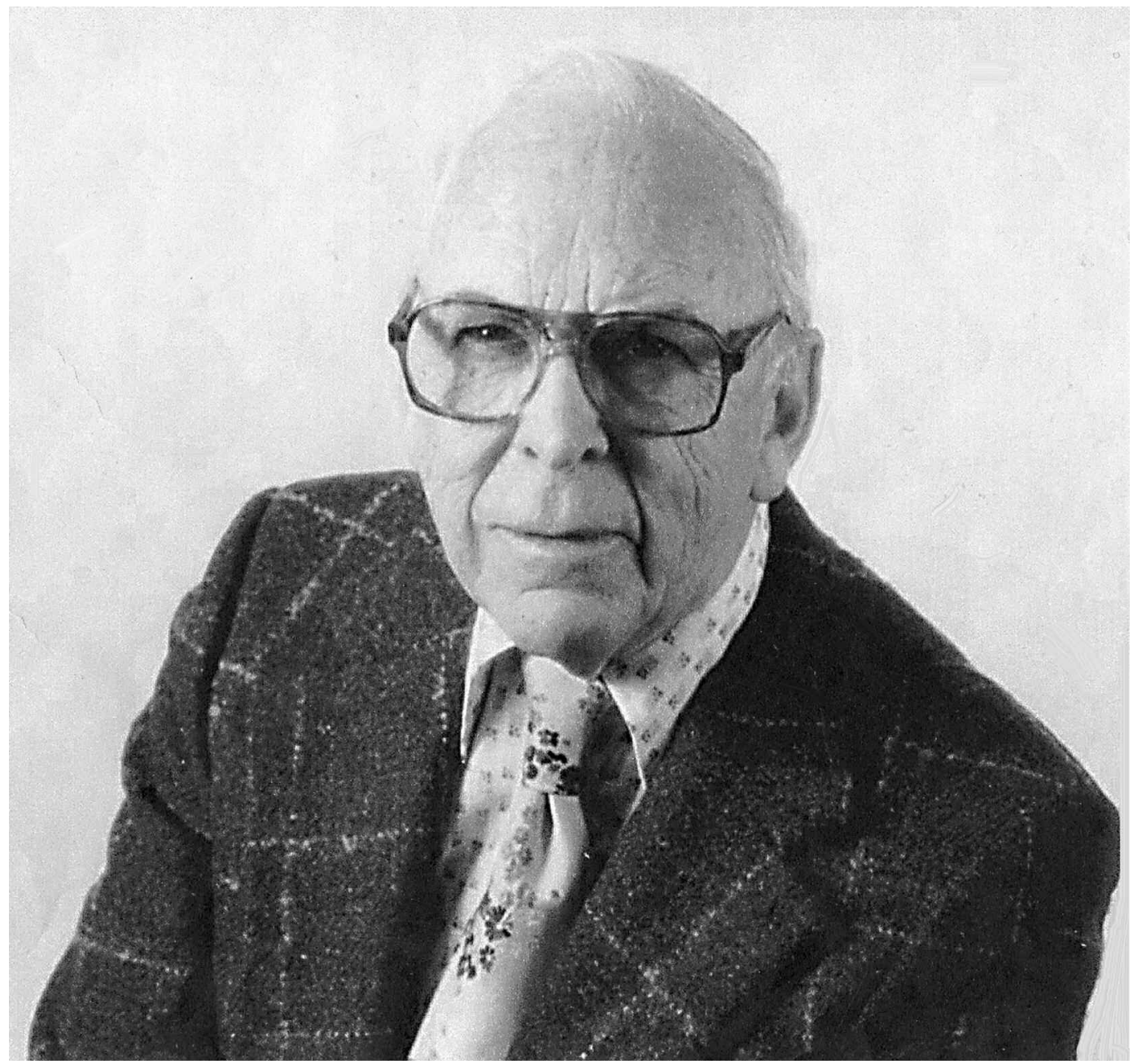

Victor Kent PREst

cogent, persuasive, and attractively illustrated synthesis available and it has served as the baseline for almost everything else that has followed.

As a great builder of Quaternary science in Canada, Vic had wide knowledge of geological and other sciences. He resumed mapping the Precambrian geology of northern Ontario for ODM (1945-1950) where he authored more than 30 maps and annual reports. He was one of the first to combine Quaternary and bedrock mapping with the release of his map of Red LakeLansdowne House. His first Quaternary publication was the Pleistocene geology of the Vermillion River system with special reference to placer gold (Prest 1949).

Vic's early Pleistocene colleagues at GSC included Jack Armstrong, Wes Blake, Jr., Bruce Craig, Bob
Fulton, John Fyles, Nelson Gadd, Eric Henderson, Owen Hughes, Bert Lee, and Archie Stalker, all of whom were to become major regional authorities, and Jaan Terasmae and Bob Mott, leaders in the development of Quaternary paleoecology in Canada. Addition of his academic and provincial geological survey friends, Bill Matthews (University of British Columbia), Earl Christiansen (Saskatchewan), Alexis Dreimanis (University of Western Ontario), Con Gravenor (University of Windsor), Paul Karrow (Waterloo University), Pierre LaSalle (Quebec), and John Elson (McGill University) largely completes the Prest cohort of Canadian Quaternary geologists.

Although he departed senior management for fulltime research in 1964, even those who joined the Sur- 
vey later, and many in outside agencies, identified the Quaternary group with Vic Prest more than with anyone else. Vic became a sort of mentor-at-large, with great moral authority and prestige, and engendered pride in the work of others. By building Quaternary science at the Survey and by mentoring and informally supervising graduate students, Vic profoundly contributed to the Canadian Quaternary community.

Vic was an enthusiastic participant in numerous field excursions in southern Canada, the northern USA, Alaska, and internationally. His GSC fieldwork took him on a High Arctic voyage that reached Ellesmere Island (Prest 1958), mapping projects in Ontario (Prest 1963), Quebec (Prest 1966; Prest and Hode-Keyser 1977) and the Maritimes. He had a special passion for the Maritimes, where his map of Prince Edward Island (Prest 1973) remains seminal, and where, with his protégé Douglas Grant, he formulated the concept of an Appalachian Ice Complex (Prest and Grant 1969; Prest et al. 1972; Prest 1977) to encapsulate the style of regional glaciation, as distinct from Laurentide glaciation. This model is still favoured by regional geologists. The Magdalen Islands in the Gulf of St. Lawrence long held his interest, because of the perplexing lack of direct evidence of Late Wisconsin glaciation and its record of older events (Prest et al. 1976). This evidence led him to portray on his ice recession map what Doug Grant termed "Prest's Problematical Pleistocene Prong", a reference to the glaciological improbability of leaving the Magdalen Islands ice free while allowing ice to extend to the edge of the Continental Shelf. The portrayal revealed Vic's preference for field evidence over theory.

Vic formally retired from GSC in 1978, and formed Veekay Consultants (1978-1994) to receive Ontario Geological Survey (OGS) surficial mapping contracts in northwestern Ontario and a Department of Indian Affairs and Northern Development contract to work in the Bebensee Lake area (Prest 1985). He continued fieldwork into his seventies, including long traverses into dense bush around the famous Red Lake gold mining camp. This work yielded a series of detailed maps (e.g., Prest 1980) that formed the basis for recent drift prospecting programs. His major syntheses included Canada's Heritage of Glacial Features (Prest 1983), the Late Wisconsin Glacier Complex paper and map (Prest 1984), a synthesis of glacial lake history in the Lake Ontario basin with Ernie Muller (Muller and Prest 1985), and maps of North American paleogeography (Dyke and Prest 1987). His two final publications dealt with the history of interpretation of the Laurentide Ice Sheet (Prest 1990) and a more specific passion, the long-distance dispersal of the distinctive erratics that he termed "omarsi" from the central part of the ice sheet (Prest et al. 2000).

Vic was an accomplished athlete and maintained a life-long interest in several sports. During the half century of his residence in Ottawa, Vic's love of tennis became super-seded by a passionate devotion to curling. He was a charter member of the City View Curling Club, founded in 1957, and President the following year. Over the years, he won many curling bonspiels both in men's and mixed rink events, and was ever a formidable shot-maker and curling strategist. He was Honorary Governor General's Curling Club President (1972), Canadian Branch (Royal Caledonia Curling Club), Council of Management (1978-1980) and Life Member (1986). With support from the Ottawa Valley Curling Association, Vic introduced Junior Curling in Eastern Ontario in 1975, and co-ordinated play with the Canadian Branch in Quebec. He also introduced "Little Rock" curling in 1983, and organized Junior and Little Rock bonspiels for the OVCA over a period of ten years. After more than 50 continuous years of winter curling, he "pushed" his last rock at age 89.

Vic's professional career accomplishments received due recognition in the form of the Johnston Medal from the Canadian Quaternary Association (the first awarded), the Gold Medal from the Royal Canadian Geographical Society, the Kirk Bryan and the Distinguished Career Awards from the Quaternary Geology and Geomorphology Division of the Geological Society of America (1993), election as a Fellow to join the distinguished scientists of the Royal Society of Cana$\mathrm{da}$, and election as Honorary Member of the International Union for Quaternary Research.

Vic and Pat enjoyed more than sixty years of mutual accomplishment. He loved the out-of-doors and experienced great pleasure whenever he had a chance to stand on a good piece of Precambrian bedrock. Vic was also very generous in his support of charitable organizations, and agencies promoting wildlife conservation and the natural sciences. He will be greatly missed by his family, and by his many friends and scientific colleagues.

\section{References}

Dyke, A. S., and V. K. Prest. 1987. The Late Wisconsin and Holocene history of the Laurentide Ice Sheet. Géographie physique et Quaternaire 41: 247-264.

Muller, E. H., and V. K. Prest. 1985. Glacial lakes in the Ontario basin. Edited by P. F. Karrow, and P. E. Calkin in Quaternary Evolution of the Great Lakes. Geological Association of Canada, Special Paper 30: 213-229.

Prest, V. K. 1939. Geology of the Keezhik-Miminiska Lake area. Ontario Department of Mines, Annual Report 48, Part 6, 8 pages.

Prest, V. K. 1941. The Precambrian of the Miminiska-Port Hope area. Unpublished Ph.D. thesis, University of Toronto, 93 pages.

Prest, V. K. 1949. The Pleistocene geology of the Vermillion River system near Capreol, District of Sudbury, Ontario (with special reference to placer gold), Ontario Department of Mines Open File.

Prest, V. K. 1952. Notes on the geology of parts of Ellesmere and Devon islands. Geological Survey of Canada, Paper 52-32, 15 pages. 
Prest, V. K. 1963. The Red Lake-Lansdowne House area, northwestern Ontario - Surficial geology. Geological Survey of Canada, Paper 63-6, 23 pages.

Prest, V. K. 1966. Glacial studies, northeastern Ontario and northwestern Quebec. In Report of Activities May to October 1965. Geological Survey of Canada, Paper 66-1: 202203.

Prest, V. K. 1969. Retreat of Wisconsin and Recent ice in North America. Geological Survey of Canada, Map 1257A, scale 1:5000 000 .

Prest, V. K. 1970. Quaternary geology of Canada. Edited by R. J. W. Douglas in Geology and Economic Minerals of Canada. Economic Geology Series (1): 676-764.

Prest, V. K. 1973. Surficial deposits of Prince Edward Island. Geological Survey of Canada, Map 1366A, scale $1: 253444$.

Prest, V. K. 1977. General stratigraphic framework of the Quaternary in eastern Canada. Géographie physique et Quaternaire 31: 7-14.

Prest, V. K. 1980. Quaternary geology of the Red Lake area, District of Kenora. Ontario Geological Survey, Preliminary Map 2484, scale 1:50 000.

Prest, V. K. 1983. Canada's heritage of glacial features. Geological Survey of Canada, Miscellaneous Report 28: 119 pages.

Prest, V. K. 1984. Late Wisconsinan Glacier Complex. Edited by R. J. Fulton, in Quaternary Stratigraphy of Canada A Canadian contribution to IGCP Project 24. Geological Survey of Canada, Paper 84-10: 21-38.

Prest, V. K. 1984. Late Wisconsinan Glacier Complex. Geological Survey of Canada, Map 1584A, 1:7 500000.

Prest, V. K. 1985. Glacial geology of the Bebensee Lake maparea (NTS 86M), Great Bear Lake region, Northwest Territories. Edited by J. A. Brophy in Contributions to the Geology of the Northwest Territories, 63-70.

Prest, V. K. 1990. Laurentide ice-flow patterns: a historical review, and implications of the dispersal of Belcher Islands erratics. Géographie physique et Quaternaire 44: 113-136.

Prest, V. K., and J. A. Donaldson. 1963. Bedrock-drift distribution, Red Lake-Lansdowne House area, Ontario. Geological Survey of Canada, Map 4-1963.

Prest, V. K., J. A. Donaldson, and H. D. Moores. 2000. The Omar story: The role of Omars in assessing glacial his- tory of west-central North America. Géographie physique et Quaternaire 54: 257-270.

Prest, V. K., and D. R. Grant. 1969. Retreat of the last ice sheet from the Maritime Provinces - Gulf of St. Lawrence region. Geological Survey of Canada, Paper 69-33, 15 pages.

Prest, V. K., D. R. Grant, H. W. Borns, I. A. Brookes, R. H. MacNeill, J. G. Ogden, J. F. Jones, T. W. Hennigar, and M. L. Parsons. 1972. Quaternary geology, geo-morphology and hydrogeology of the Atlantic Provinces. XXIV International Geological Congress, Excursion Guidebook A61C61, 79 pages.

Prest, V. K., D. R. Grant, and V. Rampton. 1968. Glacial Map of Canada. Geological Survey of Canada, Map 1253A, scale 1:5000 000 .

Prest, V. K., and J. Hode-Keyser. 1977. Geology and engineering characteristics of surficial deposits, Montreal Island and vicinity, Quebec. Geological Survey of Canada, Paper 75-29, 29 pages.

Prest, V. K., J. Terasmae, J. V. Matthews, and S. LichtiFederovich. 1976. Late-Quaternary history of Magdalen Islands, Quebec. Maritime Sediments, 12(2): 39-59.

Wilson, J. T., G. Falconer, W. H. Mathews, and V. K. Prest. 1959. Glacial Map of Canada. Geological Association of Canada, scale 1:3 801600.

\section{Examples of research publications in periph-} eral fields of science for which the work of $V$. K. Prest was basic:

Bousfield, E. L., and M. L. H. Thomas 1975. Postglacial changes in distribution of littoral marine invertebrates in the Canadian Atlantic Region. Proceedings of the Nova Scotia Institute of Science 27, Supplement 3: 37-42, 8 figures.

Dadswell, M. J. 1974. Distribution, ecology, and postglacial dispersal of certain crustaceans and fishes in eastern North America. National Museum of Canada Publications in Zoology 11: 110 pages, 20 maps.

Pielou, E. C. 1991. After the Ice age. University Chicago Press. Chicago. 366 pages.

\section{Acknowledgments}

For providing biographical material, photographs, and personal recollections, the authors are especially grateful to Patricia Prest (wife) and Sherry Armstrong (daughter). 